\title{
Hot Topics, Themes and Frontiers of Ideological and Political Education for Postgraduates in Recent Ten Years
}

\section{--Based on the Knowledge Mapping Analysis of CNKI Journals from 2011 to 2020}

\author{
Lei Li, Haiying Ma*, Hairui Sui
}

Harbin Institute of Technology, Weihai, Weihai, China

${ }^{*}$ Corresponding author. Email: mahaiying@hitwh.edu.cn

\begin{abstract}
Taking 1529 literatures in CNKI journal database from 2011 to 2020 as samples, this paper comprehensively uses bibliometrics and information visualization technology to analyze the literature characteristics in the research field of Ideological and Political education for Postgraduats in China in recent ten years, draws the knowledge map, and focuses on the analysis of research Hot topics, Themes and Frontier. The results show that there are many researchers and institutions in the field, and there is a lack of strong and stable research group. Postgraduates, Ideological and Political education, Colleges and Universities, Graduate education, Countermeasures are the main research Hot topics in the field, showing the characteristics of a wide range of Hot topics, related research is not deep enough; Under the background of the New era, Three-wide education, Collaborative education, Foster character and civic virtue and so on are the frontier and the focus of future attention in the field. Therefore, in the future, the research of Ideological and Political education for Postgraduates should focus on strengthening theoretical innovation, sticking to the problem orientation, keeping up with the pulse of The Times, and promoting the overall improvement of the Ideological and Political education for Postgraduates and related research quality in China.
\end{abstract}

Keywords: Postgraduates, Ideological and political education, Knowledge mapping, CiteSpace.

\section{近十年研究生思想政治教育研究的热点、主题及前沿 基于 2011-2020 年 CNKI 期刊文献的知识图谱分析}

\author{
李否, 马海鹰 ${ }^{*}$, 隋海瑞
}

哈尔滨工业大学 (威海), 威海, 中国

“通讯作者.邮箱: mahaiying@hitwh.edu.cn

\section{中文摘要}

以2011-2020年中国知网（CNKI）期刊库1529篇文献为样本, 综合运用文献计量方法和信息可视化技术对近十 年我国研究生思想政治教育研究领域的文献特征进行分析, 绘制知识图谱, 重点进行研究热点、主题、前沿分 析。结果显示, 该领域研究人员、机构众多, 缺少强大稳定的研究群体; 研究生、思想政治教育、高校、研究 生教育、对策等是该领域研究主要的热点主题, 呈现热点话题广泛、相关研究不够深入的特点; 新时代背景下, 
三全育人、协同育人、立德树人等是该领域的前沿和未来关注的重点。为此, 今后研究生思想政治教育研究应 着重强化理论创新、坚持问题导向、紧扣时代脉搏, 促进我国研究生思想政治教育工作和相关研究质量的整体 提升。

关键词: 研究生, 思想政治教育, 知识图谱, CiteSpace

\section{1. 前沿}

党的十八大以来, 以习近平同志为核心的党中央 高度重视研究生教育工作, 研究生教育取得长足发展, 仅就规模而言, 2020 年研究生招生人数已达 111.4 万人, 在学人数突破 300 万 $^{[1]}$ 。2020年7月, 全国研究生教育 会议在北京召开, 习近平总书记对研究生教育工作作 出重要指示强调, 适应党和国家事业发展需要, 培养 造就大批德才兼备的高层次人才 ${ }^{[2]}$ 。研究生思想政治 教育是研究生教育的重要组成部分, 要紧紧围绕立德 树人根本任务, 把思想政治教育渗透到研究生培养和 管理的各个环节, 贯穿到研究生培养和管理的全过程, 做到思想政治教育与业务培养紧密结合, 努力形成全 员育人、全方位育人、全过程育人的格局 ${ }^{[3]}$ 。

当前, 我国社会正处于转型期, 社会环境向趋利 化转变、多元社会思潮冲击主流意识形态、网络大数 据等信息技术全面发展; 同时, 研究生教育处于改革 期, 研究生规模急速扩张、教育多元化、教育管理机 制改革, 这些都给研究生思想政治教育带来新的机遇 和挑战 ${ }^{[4]}$ 。因此, 回顾和梳理研究生思想政治教育研 究的进展, 把握热点前沿, 对分析未来研究趋向, 具 有一定的理论价值和实践意义。

\section{2. 数据来源和研究方法}

\section{1. 研究方法}

本文运用可视化知识图谱工具CiteSpace软件进行 分析研究, 分别生成作者合作网络、机构合作网络、 关键词共现等图谱, 通过词频分析、聚类分析、时间 演化分析等科学计量方法, 分析我国研究生思想政治 教育研究的热点、前沿及趋势。

\section{2. 数据来源}

本文以中国知网 (CNKI) 期刊库作为文献资料的 来源，于2021年3月9日进行高级检索：以“研究 生”+“思想政治教育”为主题进行精确检索, 时间范围 2011-2020年, 来源类别为全部期刊, 共检索到1639 篇文献。本次研究的主要对象是学术论文, 结合人工 读审剔除征稿启事、会议综述、新闻报道、人物访谈
等, 共得到有效样本文献1529篇, 以Refwork格式下 载文献数据, 建立本研究的数据库。

\section{3. 年度产出分析}

发文量代表了科学知识量的变化情况, 按照时间 序列对研究生思想政治教育研究的年度文献数量进 行统计见表1, 可以从时间角度发现特定主题的发展 历程和受关注程度。从表 1 可以看出, CNKI数据库每 年收录的研究生思想政治教育研究文献数量相对比 较多, 年均153篇, 在2013年达到阶段性高点后有小 幅回落，2018年最低119篇。这表明，这十年相关研 究比较活跃, 文献产出随年份存在一定的波动, 状态 还不够稳定。

表 1. 年度产出统计表

\begin{tabular}{|c|c|c|c|}
\hline 年份 & 发文量/篇 & 年份 & 发文量/篇 \\
\hline 2011 & 160 & 2016 & 155 \\
\hline 2012 & 160 & 2017 & 129 \\
\hline 2013 & 190 & 2018 & 119 \\
\hline 2014 & 176 & 2019 & 171 \\
\hline 2015 & 136 & 2020 & 133 \\
\hline
\end{tabular}

\section{4. 研究主体分析}

\section{1. 作者及合作网络分析}

运用 CiteSpace 软件进行作者合作网络分析, 结果 见图 1。节点大小代表作者发文量多少, 节点的连线 表示节点作者存在合作关系。如图所示, “ $N=2224$, $E=1908$, 网络密度为 0.0008 ”。这表明, 在从事研究 生思想政治教育研究的 2224 位学者中, 仅存在 1908 组合作关系，合作松散。有许多单点或简单的线段、 三角形, 很少有多边形, 这进一步表明在研究生思想 政治教育研究方面作者之间交流较少、合作松散, 个 人独立创作、2-3 人小团队合作是普遍情况, 尚未形 成稳定强大的研究者群体。其中, 比较大的作者合作 网络有: 一是以沈阳农业大学的刘洋、高华、张茂仁 为核心, 高云在网络中比较突出; 二是华南农业大学 的陈䎅为核心, 蔡茂华在网络中也较为突出; 三是大 连海洋大学的杨舟、肖苏、湛圭圭为核心的团队。同 时, 北京林业大学的徐伟、北京交通大学的屈晓婷、 
吉林大学的丁红枫、山东农业大学的牛余风, 也都形 成了一定规模的学术团队。

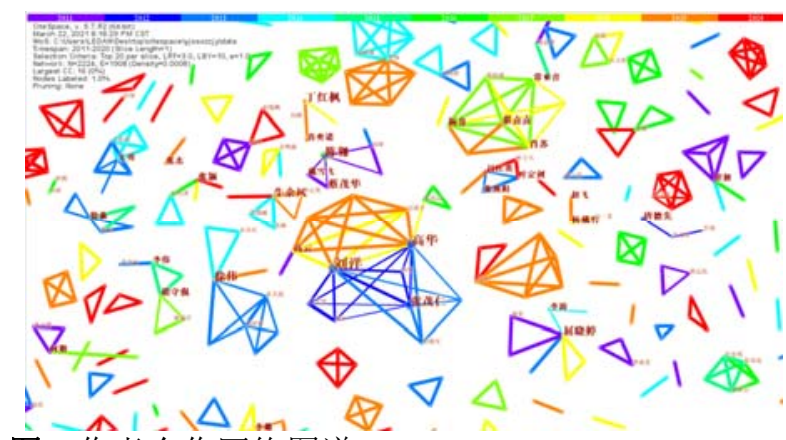

图 1 作者合作网络图谱

\section{2. 发文机构及合作网络分析}

运用CiteSpace软件进行机构合作网络分析, 结果 见图2, “N=1373, E=385, 网络密度为 $0.0004 ” 。$ 这表 明1373个机构中, 仅存在385组合作关系, 合作更是 分散。进一步分析发现, 机构间的合作具有以下特征: 一是较强的地缘性, 一般是相邻或相近的几所高校或 教育机构进行合作, 如吉林大学为核心, 与中国刑事 警察学院、长春大学、吉林师范大学、吉林艺术学院 等的合作; 二是一定的学缘性, 学科特色相近的高校 间进行合作，比如东北农大和西北农大合作; 三是机 构内部合作较多, 高校的内设学院、部门之间进行合 作, 如沈阳农业大学研究生与校内其他部门合作, 北 京大学医学部内部合作, 等等。统计表明, 按署名发 文机构的发文数量进行排序, 发文 2 篇以上的单位均 为高校。这表明, 高校是研究生思想政治教育研究的 主阵地, 体现了思想政治教育在高校中的主导地位。

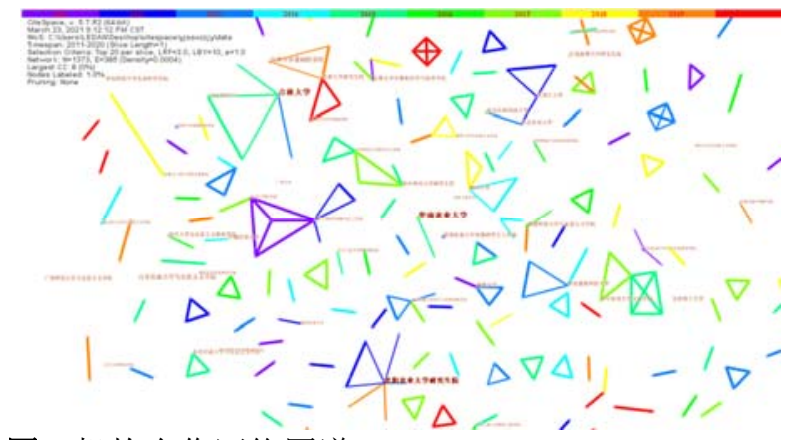

图 2 机构合作网络图谱

\section{5. 研究热点、主题及前沿}

关键词是对文献关键内容、核心观点和主要思想 的高度凝练, 分析文献中关键词出现的频次, 能发现 该领域的研究热点。在CiteSpace中选择节点KeyWord, 得到关键词共现网络如图3所示, “N=191, E=594, 网络密度为 0.0327 ”。一个节点代表一个关键词, 节点 的标签越大表示关键词的词频越高; 关键词之间的共 现用连线表示, 线与线之间的宽度表示关键词共现的 强度, 关键词周围的连线越多, 说明该关键词与更多
的关键词有关联, 进而找到与该关键词关联的其他研 究热点。

\section{1. 研究热点分析}

统计显示, 研究生（830）、思想政治教育（803） 频次最高, 在数值上具有绝对优势, 这和研究主题密 切相关; 除此之外, 较高的关键词及频数如下: 研究 生思想政治教育（100）、导师（90）、对策（61）、 高校 (61) 、辅导员 (47) 、创新 (41) 、研究生教 育 (40) 、研究生辅导员 (40)、新媒体 (34) 、研 究生导师 (33) 、思想教育 (31) 、思想政治理论课 （28）、思政教育 (28)、实效性 (28)、新时代 (27)、 思想政治 (27) 、思想政治工作 (25) 、思想政治教 育工作 (25) 、问题 (22) 、硕士研究生 (22) 、路 径 (22) 、队伍建设（21）、党建（20）、教学改革 （19）、高校研究生（15）、立德树人（15）、有效 性（15）、研究生党建（14）、管理模式（12）、现 状（11）、首要责任人（11）、协同育人（11）、三 全育人（10）、教育（10）。

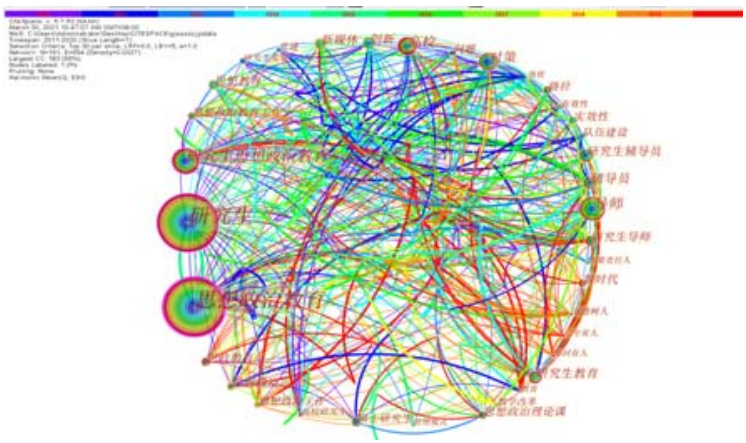

图 3 关键词共现图谱

运用CiteSpace计算各节点的中介中心性, 中介中 心度高的节点代表其在网络中起到战略中介作用, 控 制的关键词之间的信息流也就越多。中介中心性高的 关键词分别是思想政治教育 (0.47)、研究生 (0.35)、 研究生思想政治教育 $(0.29)$ 、高校 $(0.19)$ 、研究 生教育 $(0.17)$ 、导师 (0.14) 、对策 $(0.12)$ 。

综合关键词词频和中介中心性分析，这十年间的 研究热点呈现出多元化发展的特点, 主要集中在研究 生思想政治教育、高校、研究生教育、导师、对策等 方面; 同时, 大量低频关键词的出现一方面进一步表 明该领域研究的广泛性, 但也意味着在某些方面可能 存在研究不充分、深度不够的问题。

\section{2. 研究主题分析}

对关键词进行聚类分析, 如图4所示, $\mathrm{Q}=0.4035$ 表 明聚类结构显著, $S=0.7632$ 表明聚类合理、令人信服, 呈现出\#0思想政治教育、\#1辅导员、\#2问题、\#3新媒 体、\#4研究生教育、\#5思想政治状况、\#6思政教育、 \#7高校等 8 个聚类, 表示近十年来, 研究生思想政治 
教育研究主要围绕以上聚类主题开展, 形成了一定的 规模, 序号越小, 所包含的关键词越多。

“\#0思想政治教育”聚类, 直接聚集了研究生、思 想政治教育这两个最大的节点, 反映出本次研究的聚 焦性; 研究生思想政治教育实施路径、管理模式、工 作机制 ${ }^{[5-7]}$ 是研究生思想政治教育工作中关键性、深 层次重点内容。

“\#1辅导员”聚类, 聚集了导师、辅导员等反映研 究生思想政治教育工作队伍方面的关键词。导师、辅 导员是做研究生思政教育工作最重要的队伍, 导师要 发挥首要责任人的作用, 导师和辅导员要明确其角色 定位, 建立协同机制, 形成合力育人的工作模式 ${ }^{[8-10]}$, 这是“辅导员”聚类关注的重点。

“\#2问题”聚类, 聚集了对策、问题、实效性、教 学改革、高校研究生、现状等关键词。调研分析当前 研究生思政教育的状况, 存在的问题和困难, 是我们 研究的基础, 也是我们关注的重点。瞄准研究生培养 目标和研究生成长发展需求, 梳理问题、分析问题,
拿出科学合理的对策建议, 既加强思想引领, 也解决 实际困难, 在推动思想政治教育上见实效 ${ }^{[11-12]}$ 。

“\#3新媒体”聚类, 聚集了创新、新媒体、思想教 育、党建、有效性等关键词。研究生思政教育要贴近 研究生思想和学习实际, 积极利用新媒体, 探索行之 有效的教育方法, 提升教育的有效性 ${ }^{[13]}$ 。加强党建工 作, 必须结合研究生的特点, 探索合适的组织生活形 式[14]。

“\#4研究生教育”聚类, 聚集了研究生教育、新时 代、思想政治工作、立德树人等关键词。人才培养始 终是教育的重要话题, 研究生是高层次人才, 在新时 代背景下, 研究生教育应重点围绕落实立德树人根本 任务, 进一步加强和改进研究生思想政治工作, 做到 为党育人, 为国育才[15]。

由图5我们也能看出, “\#5思想政治状况”、“\#6思政教 育”、“\#7高校”等, 是研究生思想政治教育研究关注 的内容, 比如, 调查分析研究生群体思想政治状况, 思想政治理论课教学改革等。

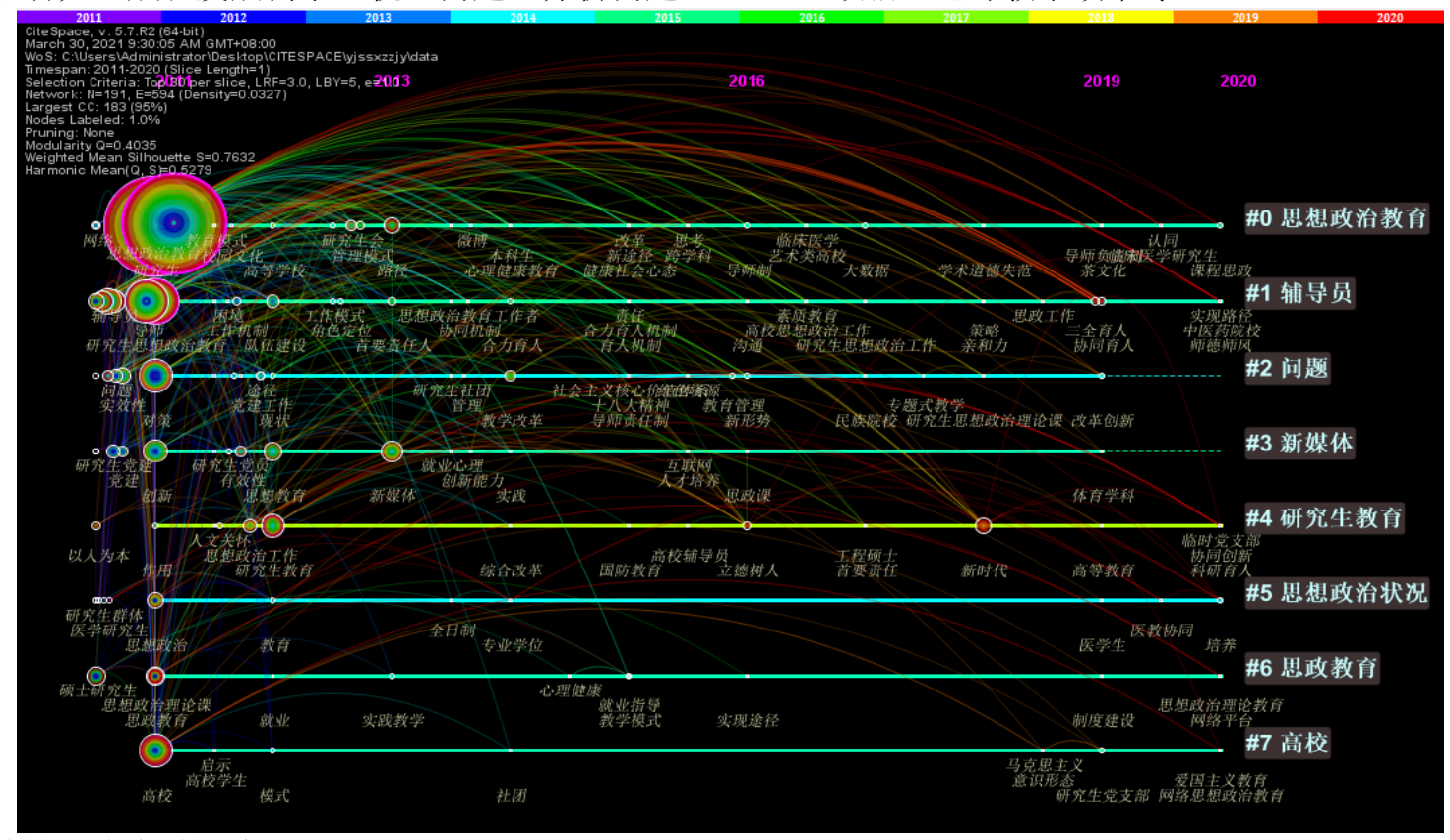

图 4 关键词聚类时间线图

\section{3. 研究前沿分析}

研究前沿通常是指一定时期内最具发展潜力的新 兴研究领域或研究主题, 也可认为是一组突现的动态 概念或潜在的研究问题。运用CiteSpace软件进行突现 检测, 结果如图5, 代表近十年来, 我国研究生思想 政治教育研究领域不同阶段的研究前沿。

2011年一2013年突现的关键词包括：思想政治教 育工作、医学研究生、工作机制、思想教育。教育部 《关于进一步加强和改进研究生思想政治教育的若 干意见》提出, “要建立健全研究生思想政治教育领
导体制和工作机制, 努力拓展新形势下研究生思想政 治教育的有效途径”。

2014-2017年突现的关键词包括: 心理健康教育、 新媒体、就业指导、新形势。该阶段究进一步丰富了 思想政治教育的内容, 既解决思想问题, 又解决与研 究生发展需求密切相关的心理健康、就业等实际问题。

2018-2020年突现的关键词包括：思想政治工作、 新时代、协同育人、三全育人、立德树人、思政教育、 研究生导师、路径等。习近平总书记在全国高校思想 政治工作会议上发表重要讲话强调, 要坚持把立德树 人作为中心环节, 把思想政治工作贯穿教育教学全过 程, 实现全程育人、全方位育人, 努力开创我国高等 教育事业发展新局面 ${ }^{[16]}$ 。中共中央国务院《关于加强 
和改进新形势下高校思想政治工作的意见》明确指出, “坚持全员全过程全方位育人。把思想价值引领贯穿 教育教学全过程和各环节, 形成教书育人、科研育人、 实践育人、管理育人、服务育人、文化育人、组织育 人长效机制”。“要推进高校思想政治工作改革创 新……完善科教融合、校企联合等协同育人模式”[17]。 教育部《关于全面落实研究生导师立德树人职责的意 见》提出, 把立德树人作为研究生导师的首要职责, 明确了研究生导师立德树人的职责: 提升研究生思想
政治素质、培养研究生学术创新能力、培养研究生实 践创新能力、增强研究生社会责任感、指导研究生恪 守学术道德规范、优化研究生培养条件、注重对研究 生人文关怀七个方面 ${ }^{[18]}$ 。这对究生思想政治工作提出 了更新、更高、更全面、更具有时代性的要求，是高 校开展研究生思想政治教育的依据, 也是学者开展相 关研究的热点前沿。尤其是其中“新时代”突现强度最 大, 更表明研究生思想政治教育应立足于时代背景, 结合时代特征、研究生群体特征来开展。

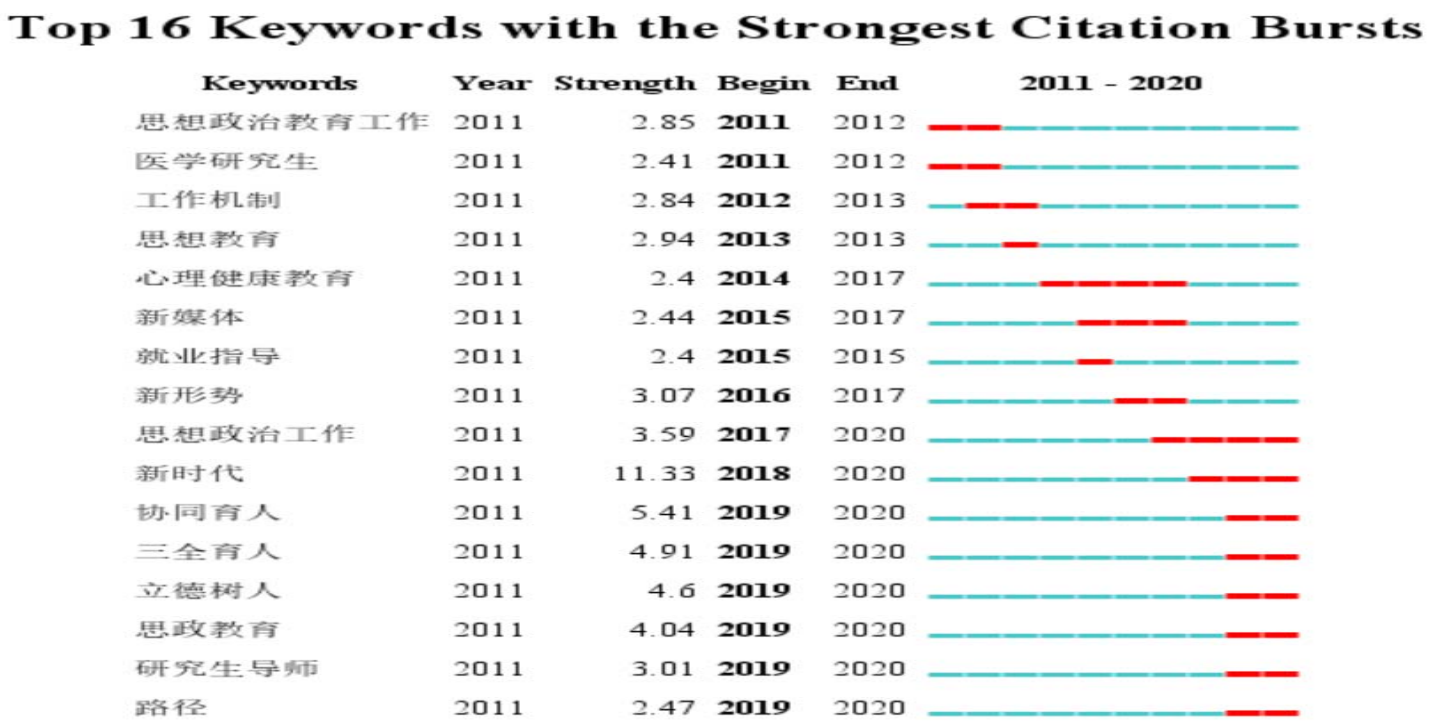

图 5 关键词突现图

\section{6. 结论与展望}

\section{1. 研究结论}

在研究机构和作者层面, 我国研究生思想政治教 育研究人员多、高产作者少，作者间合作关系不够密 切、稳定, 尚未形成强大的研究团队; 研究机构间合 作分散, 多以单位内部合作为主, 外部合作更倾向于 和地理位置相邻或相近的单位进行合作。

在研究热点前沿方面, 研究生、思想政治教育、 高校、研究生教育、对策等是该领域研究主要的热点、 主题, 呈现出热点话题广泛、相关研究不够深入的特 点; 新时代背景下, 三全育人、协同育人、立德树人 等是该领域的前沿和未来关注的重点。同时，结合重 点文献审读发现, 该领域内一般性理论分析、经验总 结类文章较多, 缺少深层次的理论分析、实证分析、 科学分析类文章。

\section{2. 未来展望}

今后我国研究生思想政治教育工作和相关研究, 可着重从以下几个方面入手。

一是研究生思想政治教育研究要强化理论创新。 要加强对党的理论创新成果的学习研究, 重点是习近 平新时代中国特色社会主义思想, 夯实马克思主义理
论基础。一是将习近平总书记教育重要论述与研究生 思想政治教育研究结合起来, 重点探究新时代研究生 思想政治教育的新要求、新挑战和新理念，不断提升 研究生思想政治教育研究的理论性、创新性。二是准 确把握研究生思想政治教育涵盖的基本内容, 可以从 界定概念、厘清范畴、规范流程等方面入手，重点加 强研究生思想政治教育的本质、研究生思想政治教育 规律、研究生成长成才规律等方面的理论研究。

二是研究生思想政治教育研究要坚持问题导向。 马克思主义最鲜明特征的特征就是问题导向, 对加强 研究生思想政治教育研究非常重要。首先, 要树立问 题意识、培育问题思维, 实事求是对待问题, 科学理 性分析问题, 对症下药解决问题。其次, 要开展研究 生思想政治教育状况调研，可以采用问卷调查、实地 考察、深入访谈等多种方式摸清现状, 深入挖掘面临 的突出矛盾和问题, 准确剖析问题根源, 从根本上提 出具有针对性、实效性的建议对策。

三是研究生思想政治教育研究要紧扣时代特征。 面对复杂多变、文化多样的时代背景, 研究生思想政 治教育如何紧扣时代主题, 紧跟时代步伐, 抢占立德 树人的先机，牢牢掌握思想政治工作的主动权和主导 权? 面对新时代研究生, 如何有效开展思想政治教育、 帮助他们筑牢思想根基? 如何让习近平新时代中国 特色社会主义思想入脑入心? 这是思想政治教育研 究者必须要思考的问题。一方面, 要始终坚持马克思 
主义指导地位，坚定正确政治方向，实现主流意识形 态的政治引领，切实提高研究生的政治素养; 另一方 面, 要真正了解研究生群体, 准确把握新时代研究生 群体的时代特征，在教育理念、内容以及方式方法改 革创新上下功夫，要充分发挥辅导员、导师、研究生 自身在思想政治教育中的作用，积极探索新媒体、新 技术与思政教育的深度融合, 让日常教育管理充满时 代感和吸引力, 从而促进思想政治育人质量的整体提 升。

\section{致谢}

哈尔滨工业大学2021年研究生教育教学改革研究 项目资助。

\section{REFERENCES}

[1] Zhao ENuo, Zhang Shuo, Wu Yue. Provide intelligent engine for high quality development $[\mathrm{N}]$. People's Daily, 2020-7-29(6).

[2] Xi Jinping made important instructions on postgraduate education: To meet the needs of the development of the party and the state, cultivate a large number of high-level talents with both political integrity and ability [N]. People's Daily, 2020-7-30(1).

[3] Opinions on Further Strengthening and improving ideological and political education for postgraduates issued by the Ministry of Education, PRC [EB/OL]. http://www.moe.gov.cn/srcsite/A12/moe_1407/s68 75/201011/t20101117_142974.html,2012-05-11.

[4] Liu Zhi, Xu Chang. Frontiers, hotspots and approaches of Ideological and political education for Postgraduates-Inductive subject analysis based on CNKI key journals [J]. Studies in Ideological Education, 2018(07)135-139.

[5] Gao Song. Ideological and political education of Postgraduates in Colleges and universities in the new era: theory, value and Practice [J]. Hubei Social Sciences, 2018(12)178-181.

[6] Wu Cuili. The construction of a new mode of Ideological and political education for postgraduates from the perspective of collaborative governance theory [J]. Academic Degrees \& Graduate Education, 2017(10)33-37.

[7] Li Chenglong. Construction of a Coordinative Mechanism of Postgraduate Ideological and Political Education [J].Journal of Graduate Education, 2013(4)13-17.

[8] Men Zhiguo, Wang Xingmei, Zhao Qian. Research on Functional Orientation and Implementation Way of Counselors in Postgraduates' Ideologica and Political Education [J]. Heilongjiang Researches on Higher Education, 2017(05)149-152.
[9] Hu Shouqiang etc. On the Long-term Mechanism of Supervisor's Role in Ideological and Political Education for Postgraduate [J].Journal of Graduate Education, 2017(02)24-27, 51.

[10] Liu Xiao, Gao Pingfa, Yuan Yonghong. Study on the cooperative education mechanism of tutors and counselors from the perspective of educational ecology [J]. China Adult Education, 2017(11)78-81.

[11] Liang Dazhan, Li Guangye, Wu Hong. Research on the current situation, problems and Countermeasures of Ideological and political education for Postgraduates [J]. Heilongjiang Researches on Higher Education, 2012(11)100-102.

[12] Ren Huaiyi etc. Preach among Peers: Innovation to Enhance the Era Sensation and Effectiveness in College Students' Ideological and Political Education [J]. Academic Degrees \& Graduate Education, 2018(09)6-10.

[13] Guo Huimei. Dilemma and Ways Out: Graduate Opinion Expression on Network in the New Media Era [J]. Academic Degrees \& Graduate Education, 2019(02)51-55.

[14] Gu Muxian, Zou Zaijin. Promoting the innovation of graduate students' Ideological and political education mechanism with the "three steps" of Party Construction [J]. Social Sciences in Guangxi, 2012(07)179-182.

[15] Jiang Lianxia etc. Practical thinking on strengthening and improving the ideological and political education of Postgraduates in the new era -Based on the investigation of the ideological and political situation of Postgraduates in Guangdong Province [J]. Studies in Ideological Education, 2019(01)128-131.

[16] Xi Jinping stressed at the National Conference on Ideological and political work in Colleges and Universities: we should combine ideological and political work with the whole process of education and teaching, and create a new prospect for the development of higher education in China $[\mathrm{N}]$. People's Daily, 2016-12-09(1).

[17] The CPC Central Committee and the State Council issued the "Opinions on strengthening and improving the ideological and political work in Colleges and Universities under the new situation" [EB/OL].

http://www.xinhuanet.com//politics/2017-02/27/c_ 1120538762.htm, 2017-02-27.

[18] Opinions on the full implementation of the graduate advisors' duty of morally education issued by the Ministry of Education, PRC [EB/OL]. http://www.moe.gov.cn/srcsite/A22/s7065/201802/t 20180209_327164.html, 2018-02-09. 